\title{
Dossiê Temático: Diversidade étnico-racial na escola: reflexões e experiências
}

\author{
Clándia Renata Pereira de Campos* \\ Deivison Moacir Cezar de Campos** \\ Paulino de Jesus Francisco Cardoso ${ }^{* *}$
}

Há quase 10 anos, a presidência da República sancionou a Lei 10.639/03 que alterou a Lei Federal de Diretrizes e Bases da Educação (LDB), no 9.394/1996, estabelecendo a obrigatoriedade da temática História e Cultura Afro-Brasileira no currículo da rede de ensino. Isso fechou um ciclo de quatro décadas de lutas do Movimento Negro pelo reconhecimento da existência de desigualdades raciais na educação. Liderados por educadores como Petronilha Beatriz Gonçalves e Silva, Vera Triunfo, Jeruse Romão, Henrique Cunha Jr, constituiu-se um pensamento negro sobre a educação brasileira que informou (e ainda informa) o sonho de uma escola republicana e democrática.

O presente número de Cadernos de Aplicação, publicação da Universidade Federal do Rio Grande do Sul, constitui uma contribuição de pesquisadores da área aos esforços de implementação da Lei e de suas Diretrizes Nacionais para o ensino de História e Cultura Afro-brasileira e Africana (Resolução CNE 001/2004), na forma de um dossiê cujos artigos e

\footnotetext{
* Mestre em História (PUCRS) e especialista em História e Cultura Afro-brasileira e Africana (Fapa). Professora de História na Escola de Ensino Fundamental Neohumanista Ananda Marga. E-mail: crp.campos@hotmail.com

* Coordenador do Curso de Comunicação Social - habilitação em Jornalismo ULBRA. Mestre em História pela PUCRS. Doutorando em Ciências da Comunicação pela UNISINOS. E-mail: deivison_campos@hotmail.com

*** Presidente da Associação Brasileira de Pesquisadores Negros - ABPN. Coordenador do Núcleo de Estudos Afro-Brasileiros - NEAB/UDESC. Doutor em História pela PUCSP. E-mail: paulino.cardoso@gmail.com
} 
relatos de experiência abordassem atividades já realizadas ou em desenvolvimento nos diferentes níveis de ensino.

Sem dúvida, a proposta de produzir um dossiê acerca da temática reflete o desafio que as escolas e professores enfrentam nos últimos anos de atender ao que determina a norma legal. $\mathrm{E}$, consequentemente, defrontando-se com um paradigma educacional colonialista e eurocêntrico. De certo modo, este dossiê reúne iniciativas, tentativas do Colégio de Aplicação e de outras instituiçốes de ensino. Em verdade, o ponto de partida para a seleção dos trabalhos aqui publicados foi esse contato com o chão da escola, de ser expressão de demandas surgidas da prática em sala de aula.

Para nossa felicidade, o interesse na temática fez com que o dossiê recebesse o maior número de contribuições das últimas edições de Cadernos do Aplicação, segundo os editores. São expressão de experiências múltiplas, historicamente datadas. Por essas razóes, entendemos que as atividades aqui relatadas não devem ser lidas como receitas, mas como provocações para que o professor encontre junto com seus alunos, modos diversos de conhecer e valorizar a pluralidade cultural presente no país, e não monocultural, como tem ocorrido nos últimos séculos. Inverte-se, assim, a lógica a partir da qual os currículos têm sido construídos no Brasil.

A Lei faz parte de um conjunto de políticas afirmativas reivindicadas pelos movimentos sociais negros e foi resultado da luta dos africanos e afrodescendentes cativos, libertos e livres, na Escravidão e no pós-Abolição. Na década de 1970, a proposta do Grupo Palmares, liderado pelo saudoso Prof. Oliveira Silveira, tornando o 20 de novembro em Dia Nacional da Consciência Negra, por exemplo, colaborou para desencadear uma revisão da historiografia brasileira de modo a incluir as experiências dos africanos e seus descendentes. No manifesto escrito em 1972, o grupo defendia que "é tomando consciência desses fatos que o negro fica sabendo que ele tem uma história para se orgulhar, e [a partir disso] vai participar de outra maneira da sociedade 
brasileira, autovalorizando-se" (REVISTA ZH, 1972). Isso porque a escola não está restrita ao ensino de conteúdos, mas tem como função constituir indivíduos em cidadãos para viver em sociedade.

O cumprimento da Lei trata-se então, como refere o parecer CNE 003/04, do Conselho Nacional de Educação, de uma "decisão política, com fortes repercussões pedagógicas", visando reverter o silêncio dos currículos sobre a cultura e a história dos afro-brasileiros. A atual situação dos currículos ainda se parece com o relato feito por Steve Biko sobre o ensino na África do Sul, no início dos anos 1970, durante o Apartheid: "Não é de estranhar que a criança africana aprenda na escola a odiar tudo o que herdou. A imagem que lhe apresentam é tão negativa que seu único consolo consiste em identificar-se ao máximo com a sociedade branca" (BIKO, 1972).

Trata-se, aqui como lá, de uma escola comprometida com projetos institucionais hegemônicos, caracterizado por sua natureza eurocêntrica, colonial e racista. Projeto totalitário que excluiu da educação escolar outros saberes, provocando a invisibilidade de indivíduos e culturas. Como resultado, constroem-se mitos e as relações de pertencimento ao processo de escolarização dos estudantes não brancos mantém-se em permanente tensionamento. A lei busca corrigir essas incoerências históricas e seus resultados sociais, demandando novas perspectivas epistemológicas, considerando que não há epistemologia neutra (SANTOS, 1985).

A transformação necessária passa, dessa forma, pelo engajamento de professores e estudantes nesse projeto de mudar as formas de conhecer e apropriar-se das contribuições das populações africanas e afro-brasileiras, a fim de se ter uma melhor compreensão do mundo em que vivemos. O dossiê aqui apresentado busca, de alguma forma, indicar pistas sobre o saber-fazer necessário para que a lei deixe de ser apenas um proposição e se torne uma realidade. 


\section{Referências}

BIKO, Steve. Escrevo o que eu quero. Seleção dos principais textos de Steve Biko. São Paulo: Ática, 1990.

REVISTA ZH. Os quilombos de Palmares. Zero Hora. Porto Alegre, 19/11/1972.

SANTOS SOUZA, Boaventura de; MENEZES, Maria Paula. Epistemologias do Sul. São Paulo: Cortez, 2010.

SANTOS, Boaventura de Souza. [1986] Um discurso sobre a ciência. Disponível em: $\quad<\mathrm{http}: / / w w w . s c r i b d . c o m / d o c / 6982113 /$ BoaventuraDiscurso-Sobre-a-Ciencia>. Acesso em: 10 jul. 2012 